\title{
A PCR-Based Assay for Detection of Puccinia striiformis f. sp. tritici in Wheat
}

\author{
J. Zhao, X. J. Wang, C. Q. Chen, L. L. Huang, and Z. S. Kang, College of Plant Protection and Shaanxi Key \\ Laboratory of Molecular Biology for Agriculture, Northwest A\&F University, Yangling, Shaanxi 712100, P. R. China
}

\begin{abstract}
Zhao, J., Wang, X. J., Chen, C. Q., Huang, L. L., and Kang, Z. S. 2007. A PCR-based assay for detection of Puccinia striiformis f. sp. tritici in wheat. Plant Dis. 91:1669-1674.

Monitoring the pathogenic fungus of wheat stripe rust, Puccinia striiformis f. sp. tritici, plays a key role in effective control of the disease. In the present study, we developed a specific and sensitive polymerase chain reaction (PCR) assay for detecting the pathogen in wheat (Triticum aestivum) leaves. A pair of primers (PSF and PSR) was designed based on the internal transcribed spacer (ITS) region sequence of P. striiformis $\mathrm{f}$. sp. tritici. PCR products that were amplified with universal primers ITS1 and ITS4 were cloned into pGEM-T Easy vectors and sequenced. The ITS sequence was compared with those of $P$. striiformis $\mathrm{f}$. $\mathrm{sp}$. tritici, $P$. triticina, $P$. graminis f. sp. tritici, Blumeria graminis f. sp. tritici, Fusarium graminearum, Rhizoctonia cerealis, and Bipolaris sorokiniana, which are associated with early symptoms of foliar diseases on wheat. Specificity of the primers was tested in the PCR assays using DNA extracted from all tested $P$. striiformis f. sp. tritici isolates, other fungal species, and healthy and infected wheat leaves sampled around stripe rust foci in wheat fields, different days after inoculation with $P$. striiformis f. sp. tritici, as well as asymptomatic wheat leaves sampled around stripe rust foci in the fields. A PCR product of $169 \mathrm{bp}$ was amplified from DNA of all P. striiformis $\mathrm{f}$. sp. tritici isolates. The primers did not amplify DNA from the other tested fungal species. The pathogen was detected from asymptomatic wheat leaves inoculated with $P$. striiformis $\mathrm{f}$. sp. tritici under greenhouse conditions, as well as leaves sampled around stripe rust foci in wheat fields. Under optimum conditions, the PCR assay was highly sensitive and required only $0.1 \mathrm{pg}$ of the target DNA for a detectable and reliable amplification with the PSF and PSR primers.
\end{abstract}

Additional keywords: pathogen detection, Triticum aestivum, yellow rust

Stripe rust (yellow rust), caused by Puccinia striiformis Westend. f. sp. tritici Erikss., is one of the most important diseases of wheat in the world $(21,26)$. The fungal pathogen is an obligate parasite and can infect wheat plants throughout the wheat growing season. Stripe rust oversummers on volunteer wheat plants growing in the field after harvesting and can infect seedlings of winter wheat (2). Generally, uredia of the pathogen can be seen on the leaf surface of the infected wheat plants about 14 days after infection under the optimum conditions (2). In China, the disease is the most destructive on common wheat (Triticum aestivum L.) and can cause severe yield losses when susceptible cultivars are widely grown and weather conditions are favorable for the disease. Significant wheat yield losses occurred in the northwest, southwest, and north of China in 1950, 1964, 1990, and 2002 (14,28-30).

Among the methods available for control of stripe rust, growing resistant wheat

Corresponding author: Z. S. Kang

E-mail: kangzs@nwsuaf.edu.cn

Accepted for publication 18 July 2007.

doi:10.1094/PDIS-91-12-1669

(C) 2007 The American Phytopathological Society cultivars is the most efficient, economical, and environmentally friendly $(16,20)$. However, rapid changes in the pathogen virulence can overcome stripe rust resistance in wheat cultivars $(4,17)$. Use of fungicides is still a major approach to control the disease $(2,15)$. Fungicides should be used in a timely manner to achieve effective control of the disease. Therefore, monitoring the disease in the field plays a key role in effective control of stripe rust. Once the disease becomes epidemic, fungicide application can be too late to be economically effective. If the pathogen can be detected within its latent period, fungicides can be applied before the epidemic starts. Thus, the risk of the disease to wheat can be significantly reduced.

In recent years, molecular techniques based on polymerase chain reaction (PCR) have become useful tools to study plant pathogens and to develop more reliable and quicker detection methods $(6,19,31)$. The internal transcribed spacer (ITS) regions in ribosomal DNA (rDNA) are especially suitable for targets. Specific and sensitive detection is possible with only small amount of DNA templates (9). Specific primers based on ITS region already have been used for specific detection of a numerous plant pathogens $(8,10,25,32$, $35,37)$. Compared with traditional diagnostic methods, a major advantage of the technique based on PCR is the elimination of culture of the target organism prior to detection. Furthermore, the technique is very specific, sensitive, and rapid $(11,13,27)$. Because P. striiformis f. sp. tritici is a biotrophic fungus and obligate parasite, the fungus is difficult to culture on artificial media. Therefore, the PCRbased technique should be more useful for detecting the stripe rust pathogen in plant tissues than other fungi that can be cultured easily on artificial nutrition media. The objectives of this study were to develop specific primers to detect $P$. striiformis $\mathrm{f}$. sp. tritici and to detect the pathogen from infected wheat leaves in fieldgrown wheat plants using the specific primers in a PCR assay.

\section{MATERIALS AND METHODS}

Fungal isolates. Except for an isolate of P. graminis f. sp. tritici, the causal agent of wheat stem rust, which was provided by the Department of Plant Protection at Shenyang Agricultural University, China, all other fungal isolates were from the culture collection of the Institution of Phytopathology at Northwest A\&F University, China (Table 1). Isolates of $P$. striiformis $\mathrm{f}$. sp. tritici, $P$. triticina, and $P$. graminis f. sp. tritici were multiplied on wheat cv. Mingxian 169 using the method of $\mathrm{Li}$ and Shang (14). An isolate of Blumeria graminis f. sp. tritici, the causal agent of wheat powdery mildew, was increased on Mingxian 169 using a method similar to that of wheat rusts. Other fungi were cultured on potato dextrose agar (PDA) media for 3 days. Mycelia of each isolate were transferred into liquid PDA media for 4 days with agitation at room temperature. Mycelia were filtered, dried using a vacuum pump, and then kept in a $-80^{\circ} \mathrm{C}$ freezer until DNA extraction.

DNA extraction. Genomic DNA of each isolate of all tested fungal species was extracted using the method described by Chen et al. (3). The extracted DNA of each isolate was quantified using a Biophotometer (Eppendorf, Germany) and adjusted to a final concentration of $10 \mathrm{ng} / \mu \mathrm{l}$ for PCR amplification.

ITS amplification, cloning, and sequencing. Five isolates of $P$. striiformis $\mathrm{f}$. sp. tritici and one isolate each of $P$. graminis f. sp. tritici and $P$. triticina were used in PCR amplification of the ITS region with universal primers, ITS1 (5'TCCGTAGGTGAACCTGCGG-3') and ITS4 (5'-TCCTCCGCTTATTGATATGC$\left.3^{\prime}\right)$ (34). PCR amplification were performed in a $25-\mu \mathrm{l}$ mixture containing $2.5 \mu \mathrm{l}$ 
of 10× PCR buffer (Mg-free) (MBI Fermentas, MD), $2 \mathrm{mM} \mathrm{MgCl} 2,0.15 \mathrm{mM}$ each of dNTPs (Sino-American Biotech. Company, Henan, China), $0.8 \mu \mathrm{M}$ each of the two primers, 1 unit of Taq DNA polymerase (MBI Fermentas), and $20 \mathrm{ng}$ of template DNA. PCR parameters were: an initial denaturation for $5 \mathrm{~min}$ at $94^{\circ} \mathrm{C}$; then, 30 cycles consisting of denaturation at $94^{\circ} \mathrm{C}$ for $30 \mathrm{~s}$, annealing at $51^{\circ} \mathrm{C}$ for 40 $\mathrm{s}$, and extension at $72^{\circ} \mathrm{C}$ for $90 \mathrm{~s}$; and a final extension at $72^{\circ} \mathrm{C}$ for $7 \mathrm{~min}$. Sterilized distilled water was used as a negative control in every experiment to test for presence of contamination in PCR reagents. PCR products were electrophoresed in a $1 \%(\mathrm{wt} / \mathrm{vol})$ agarose gel containing ethidium bromide $(0.5 \mu \mathrm{g} / \mathrm{ml})$ in $1 \times$ Tris-

PCR products amplified with the universal primers ITS1 and ITS4 from various $P$. striiformis f. sp. tritici were similar in size; therefore, specific primers were designed for the detection of $P$. striiformis $\mathrm{f}$. $\mathrm{sp}$. tritici. In order to achieve this goal, all target PCR products were excised from the agarose gel, purified with Gel Extraction Mini Kit (Huanshun Biotech Corp., Shanghai, China), and cloned into a pGEM-T Easy Vector (Promega Corp., acetate-EDTA buffer.

Madison, WI) according to the instructions provided by the manufacturer. White colonies were selected with a suitable insert (22), and sequencing of the complete ITS region was carried out on an ABI PRISM 377 DNA Sequencer (Applied Biosystems, Foster City, CA).

Primer design. Sequences of rDNA in the ITS region were aligned for all of $P$. striiformis $\mathrm{f}$. sp. tritici isolates and other fungi using DNAMAN (version 4.0; Lynnon Biosoft, Quebec, Canada). Forward (PSF) and reverse (PSR) primers specific to $P$. striiformis $\mathrm{f}$. sp. tritici were designed using the Primer Premier 5.0 software (Premier Biosoft International., CA, USA), which sets oligonucleotide size, PCR product size, positional constraints, and G$\mathrm{C}$ content within the source sequence. The two primers were synthesized by Sango Bio. Engineering \& Tech. Co. Ltd. (Shanghai, China) to yield a PCR product of 169 bp by the set parameters.

Specificity and sensitivity of the $P$. striiformis f. sp. tritici primers. All DNA samples, including five isolates of P. striiformis f. sp. tritici and six isolates of other fungi, were used in PCR amplification with the PSF and PSR primers (Table 1). In order to test the sensitivity of the prim-

Table 1. Isolates of Puccinia striiformis f. sp. tritici and other fungi were used in polymerase chain reaction (PCR) assays

\begin{tabular}{llcc}
\hline Fungal species & Isolate $^{\mathbf{a}}$ & ITS1/ITS4 $^{\mathbf{b}}$ & PSF/PSR $^{\mathbf{b}}$ \\
\hline$P$. striiformis f. sp. tritici & $\mathrm{Su} 11$ & + & + \\
$P$. striiformis f. sp. tritici & $\mathrm{HY} 46$ & + & + \\
$P$. striiformis f. sp. tritici & $\mathrm{CYR}-23$ & + & + \\
$P$. striiformis f. sp. tritici & $\mathrm{CYR}-31$ & + & + \\
$P$. striiformis f. sp. tritici & $\mathrm{CYR}-32$ & + & + \\
$P$. graminis f. sp. tritici & $\mathrm{Pgt}$ & + & - \\
$P$. triticina & $\mathrm{Pt}$ & + & - \\
Blumeria graminis f. sp. tritici & $\mathrm{Bgt}$ & + & - \\
Fusarium graminearum & $\mathrm{Fg}$ & + & - \\
Rhizoctonia cerealis & $\mathrm{Rc}$ & + & - \\
Bipolaris sorokiniana & $\mathrm{Bs}$ & + & - \\
\hline
\end{tabular}

${ }^{\text {a }}$ Su11 = Suwon 11, HY46 = Hybrid 46, and CYR = Chinese yellow rust.

${ }^{\mathrm{b}}$ PCR amplification positive (+) or negative (-) with the universal primers internal transcribed spacer (ITS) 1 and ITS4 and forward (PSF) and reverse (PSR) primers specific to $P$. striiformis $\mathrm{f}$. sp. tritici. ers specific for detection, $1 \times 10^{-3}$ to $1 \times 10^{4}$ pg of serially diluted DNA of the $P$. striiformis f. sp. tritici isolate CYR-32 were used as DNA templates for PCR amplification. The following PCR amplification conditions using the PSF and PSR primers were chosen: an initial denaturation for $5 \mathrm{~min}$ at $94^{\circ} \mathrm{C}$; then, 35 cycles of denaturation for 30 $\mathrm{s}$ at $94^{\circ} \mathrm{C}$, annealing for $40 \mathrm{~s}$ at $60^{\circ} \mathrm{C}$, and extension for $90 \mathrm{~s}$ at $72^{\circ} \mathrm{C}$; and a final extension for $7 \mathrm{~min}$ at $72^{\circ} \mathrm{C}$. PCR products were analyzed on $2 \%$ agarose gels and DNA stained by ethidium bromide.

PCR amplification from infected leaves and samples collected in wheat fields. To further confirm effectiveness of primers PSF and PSR in detection of $P$. striiformis $\mathrm{f}$. $\mathrm{sp}$. tritici in the field, the primers were used to amplify DNA samples from wheat leaves harvested daily from 1 to 6 days after inoculation with urediniospores of isolate CYR-32 in a greenhouse. Similar tests were conducted with DNA samples from wheat leaves without any symptoms and signs around stripe rust foci resulted from natural infection in fields in spring 2004. DNA was extracted from the wheat leaves according to the method described by Lodhi et al. (18). The PCR amplification was performed with primers PSF and PSR using the conditions as described above.

\section{RESULTS}

Design of PCR primers. A DNA fragment of approximately $660 \mathrm{bp}$ from the ITS region was amplified from five $P$. striiformis $\mathrm{f}$. sp. tritici isolates, a $P$. triticina isolate, and a $P$. graminis f. sp. tritici isolate using the universal primers ITS1/ITS4 (Fig. 1). The sequenced ITS region data showed that all isolates of $P$. striiformis $\mathrm{f}$. sp. tritici, including the published sequence of $P$. striiformis f. sp. tritici (GenBank accession number AY114292), had the identical ITS sequence, except for two isolates (Su11 and CYR-23) that had mutations at two or three bases (data not

Puccinia striiformis f. sp. tritici

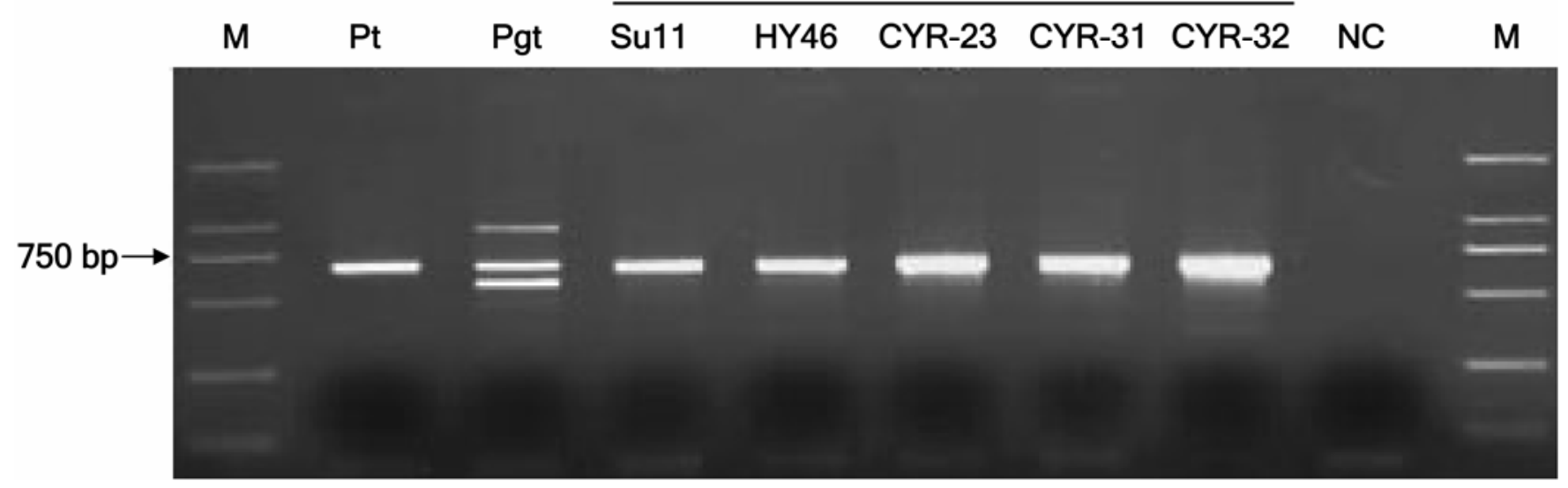

Fig. 1. Ethidium bromide-stained agarose gel of polymerase chain reaction products with universal primers internal transcribed spacer (ITS) 1 and ITS4 from five isolates of Puccinia striiformis f. sp. tritici, P. triticina $(\mathrm{Pt})$, and . graminis $\mathrm{f}$. sp. tritici $(\mathrm{Pgt})$. NC = negative control (sterile water) and M = DNA ladder (DL-2000, Takara). 
shown). In order to design a pair of primers specific for $P$. striiformis $\mathrm{f}$. sp. tritici, the sequence of the ITS region of isolate CYR-32 (Table 1) was aligned with the ITS sequences of $P$. graminis f. sp. tritici, $P$. triticina, and other fungi in the GenBank database (i.e., accession numbers BK005224, Fusarium graminearum; $\mathrm{AB} 022376$, B. graminis f. sp. tritici; DQ337383, Bipolaris sorokiniana; and AR256600, Rhizoctonia cerealis). However, the $P$. striiformis f. sp. tritici isolates had significantly different sequences from those of $P$. graminis f. sp. tritici, $P$. triticina, and other fungal species. Therefore, the designed primer pair would differentiate $P$. striiformis f. sp. tritici from the other fungi. A pair of $P$. striiformis $\mathrm{f}$. sp. tritici-specific primers (5'-GGATGT TGAGTGCTGCTGTAA-3' and 5'-TTGA GGTCTTAAGGTTAAAATTG-3'), which were designed according to the consensus sequence of the alignment of the ITS sequence of all of the sequenced isolates of $P$. striiformis f. sp. tritici and the other two Puccinia isolates, were used as the $P$. striiformis f. sp. tritici forward (PSF) and reverse (PSR) primers (Fig. 2).

Specificity and sensitivity of the PSF and PSR primers. In the specificity test, all isolates listed in Table 1 were used in PCR actions with primers PSF and PSR. All isolates of $P$. striiformis $\mathrm{f}$. sp. tritici had the expected single band of $169 \mathrm{bp}$ (Table 1; Fig. 3) and all other fungal isolates and genomic DNA samples of healthy plants did not have the band (Table 1; Fig. 3 ). A dilution series of DNA of the P. striiformis f. sp. tritici isolate CYR-32 was tested to determine the sensitivity of the PCR assay using the PSF and PSR primers. For the reliability of PCR amplification with the PSF and PSR primers, as little as $0.1 \mathrm{pg}$ of DNA from $P$. striiformis f. sp. tritici was required to produce the single PCR product (Fig. 4). No PCR product was obtained from the negative control.

Detection of $P$. striiformis f. sp. tritici from inoculated plants in the greenhouse and naturally infected leaves from fields. To test the reliability of the P. striiformis f. sp. tritici-specific primers PSF and PSR, the PCR assay was conducted with the specific primer pair to detect the pathogen in wheat leaves in 1 to 6 days consecutively after inoculation. The wheat leaves did not show any visible symptoms and signs. Fragments of the expected 169 bp were amplified from total DNA from the infected wheat leaves (Fig. 5). No PCR band was amplified from healthy leaves of wheat and negative control (sterile water). In addition, the 169-bp band was amplified from infected leaves collected from asymptomatic wheat leaves around stripe rust foci of natural infection (Fig. 6). The marker results indicated the presence of the pathogen, which was confirmed by sporulation observed 4 days later.

\section{DISCUSSION}

In this study, the specific primers PSF and PSR were developed for P. striiformis f. sp. tritici using the ITS region of rDNA. This pair of primers was used in PCR reactions to detect $P$. striiformis $\mathrm{f}$. sp. tritici. The PCR assay had high specificity because the specific fragment was amplified from all tested $P$. striiformis f. sp. tritici but did not amplify any band from other fungi associated with foliar diseases on wheat or from noninfected wheat leaves. In the tests with field samples, the PCR assay detected the pathogen in wheat leaves inoculated with urediniospores. This specific detection for the pathogen also was performed successfully in wheat leaves without any visual symptom and sign, which were collected around stripe rust foci in wheat fields. The results of the PCR assay showed high sensitivity, as indicated by amplification with as little as $0.1 \mathrm{pg}$ of genomic DNA.

PCR techniques offer powerful tools to detect plant-pathogenic fungi. In recent years, randomly amplified polymorphic DNA (RAPD) markers were commonly used to develop specific primers. RAPD

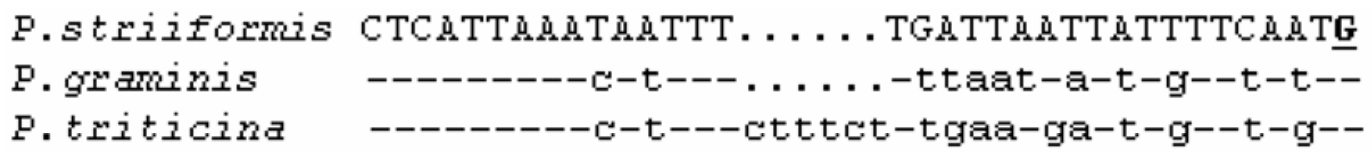

P.strififomis GATGTTGAGTGCTGCTGTAATTẢ. .GCTCACTTTAAATAT P. graminis -----------t----a------ta--------------P. triticina P.striiformis P. graminis P. triticina ATAMGTCACTTTTCTẢ. TÄATTGGATTGACTTGGTGT. . --------------a-a--------------------- . --c-----------a-a-g-------------------gt P.strififomis AATAMTTTTAT. . CATCACATCAMGGATTGTAGCAATAC. P. graminis P. triticina P.strififomis P. graminis P. triticina

443

481

518

555

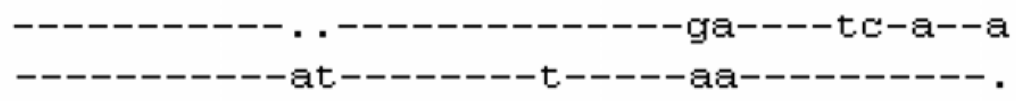

. . TGCCATCTTÁTTT. . ẢAGGGAGACTCCTẢẢÁCCCA ct---------t---gta-caa-------------c--a. t-------------aatg-aa------t-----g-a---

590

\footnotetext{
P.striifomis ATTTTAnCCTT. . AnGACCTCAnẢTCAGGTGGGACTACC

P. graminis $\mathrm{ta}-\mathrm{c}--\mathrm{t} \mathrm{t}--\mathrm{t} \mathrm{t}-----------------------$ P. triticina tacs--tett-act ------------------------
}

Fig. 2. Sequence alignment of the partial ribosomal DNA internal transcribed spacer (ITS) region of Puccinia striiformis f. sp. tritici (isolate CYR-32), $P$. triticina, and P. graminis f. sp. tritici. The P. striiformis f. sp. tritici-specific primers PSF (forward) and PSR (reverse) were designed based on the underlined bold regions. 


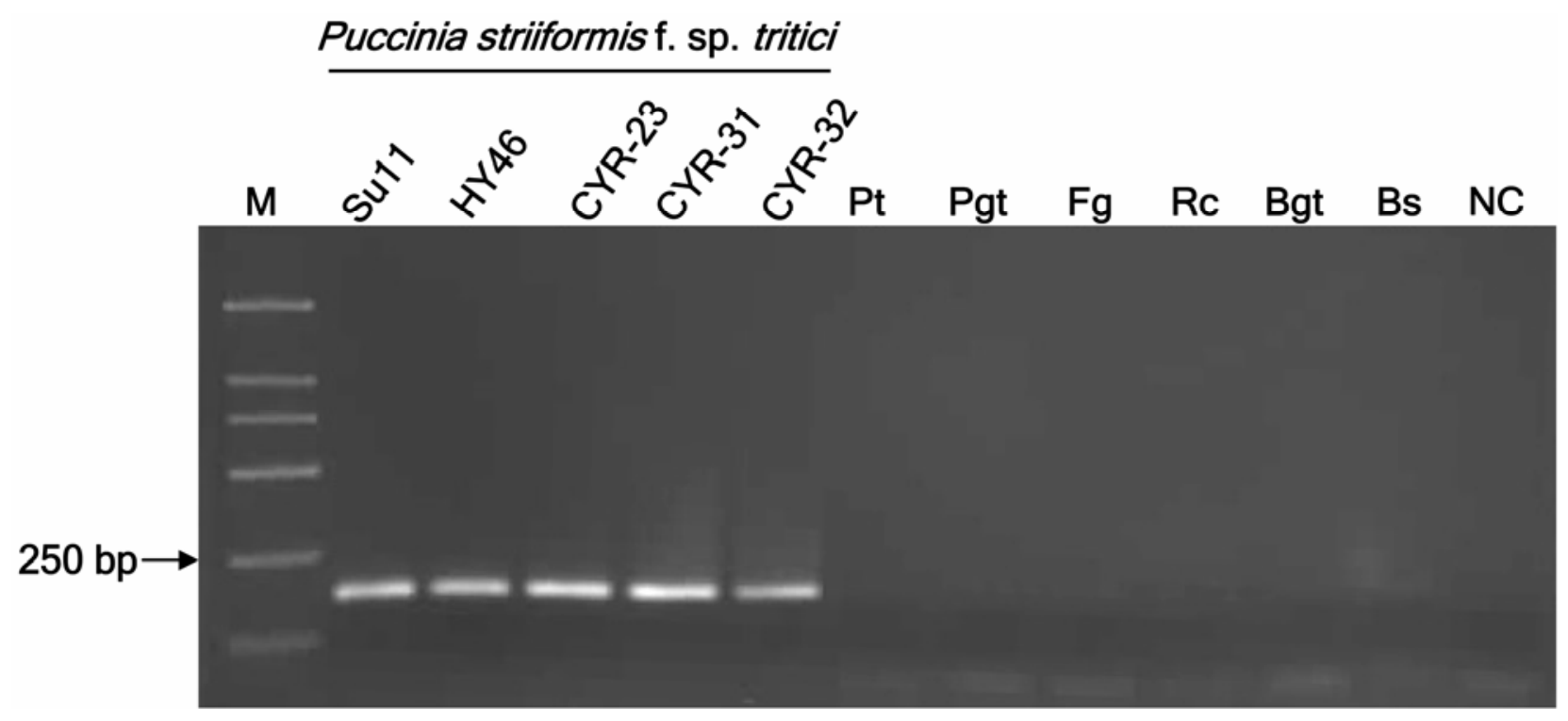

Fig. 3. Agarose gel showing a specific band amplified by polymerase chain reaction (PCR) with the forward (PSF) and reverse (PSR) primers from Puccinia striiformis $\mathrm{f}$. sp. tritici isolates, but not from isolates of other pathogenic fungi. DNA templates were extracted from five isolates of $P$. striiformis f. sp. tritici and one isolate each of P. triticina (Pt), P. graminis f. sp. tritici (Pgt), Fusarium graminearum $(\mathrm{Fg})$, Rhizoctonia cerealis $(\mathrm{Rc})$, Blumeria graminis $\mathrm{f}$. sp. tritici (Bgt), and Bipolaris sorokiniana (Bs). PCR products were separated by $1 \%$ agarose gel electrophoresis. $\mathrm{NC}=$ negative control $($ sterile water) and $\mathrm{M}=\mathrm{DNA}$ ladder (DL-2000, Takara).

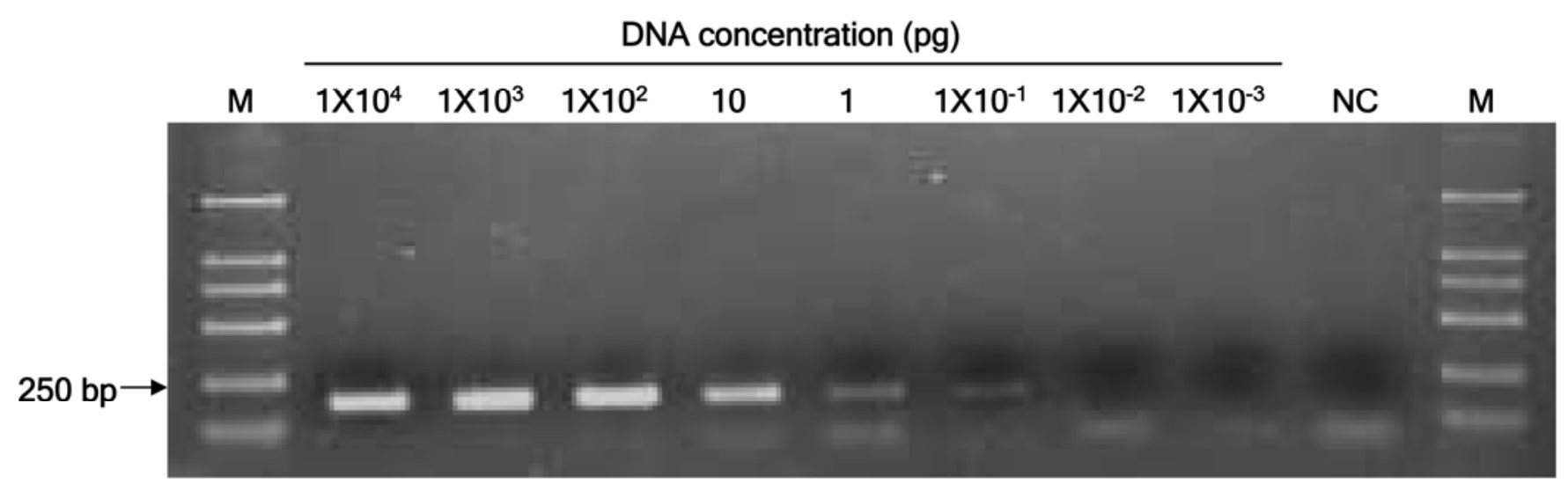

Fig. 4. Ethidium bromide-stained agarose gel showing sensitivity of Puccinia striiformis f. sp. tritici-specific primers PSF (forward) and PSR (reverse) using a series of DNA dilutions (ranging from $1 \times 10^{4}$ to $1 \times 10^{-3} \mathrm{pg}$ ) from isolate CYR-32 as templates. NC = negative control (no DNA) and M $=$ DNA ladder (DL-2000, Takara).

markers have been used successfully to design specific primers for detection of $P$. striiformis f. sp. tritici races CYR-31 (1) and CYR-29 (12). Although a family of moderately repetitive DNA sequences specific to the genome of $P$. striiformis $\mathrm{f}$. sp. tritici were identified (24), specific PCR primers for detection of the pathogen in wheat leaves have not been previously reported. To our knowledge, this study was the first to address the issue of the early detection of the wheat stripe rust pathogen.

The ITS regions of rDNA have been used to design specific primers for identification of plant pathogens $(5,37,38)$. The ITS regions show considerable variations among different fungal species, but generally are conserved within a species $(32,33,36)$, which makes the ITS region a good candidate for developing specific PCR primers. In addition, rDNA is present in multiple copies in most fungal genomes. Therefore, PCR assays that amplify rDNA should be more sensitive than those directed toward single-copy genes (7). Thus, the $P$. striiformis f. sp. tritici-specific primers were designed using the ITS regions of rDNA in the present study.

The expected PCR product was amplified from asymptomatic wheat leaves at different time intervals after inoculation with $P$. striiformis f. sp. tritici. The result demonstrates that the PCR assay with the designed primer pair is a reliable method for early detection of the pathogen before seeing the disease symptoms and pathogen signs. Although the specificity and sensitivity of the primers are good for detecting $P$. striiformis f. sp. tritici, further work on sampling is needed to determine how sensitive the PCR assay is regarding percentage of plants infected, which largely depends upon appropriate sampling methods. Importantly, if the pathogen can be detected early by the PCR assay at the initial disease development stage, fungicides can be applied before wheat stripe rust becomes epidemic, which may greatly reduce the disease risk.

The PCR assay used in this study was not intended to quantify DNA in samples. It can be used only to detect the presence and absence of $P$. striiformis f. sp. tritici in wheat leaves. However, real-time PCR assays have been developed and used successfully to quantify target DNA (23). Future studies using the real-time PCR technique should determine the pathogen level in infected wheat leaves before sporulation.

\section{ACKNOWLEDGMENTS}

This research was supported by the "973" Research Program of China (no. 200611D100203), the 
Days after inoculation

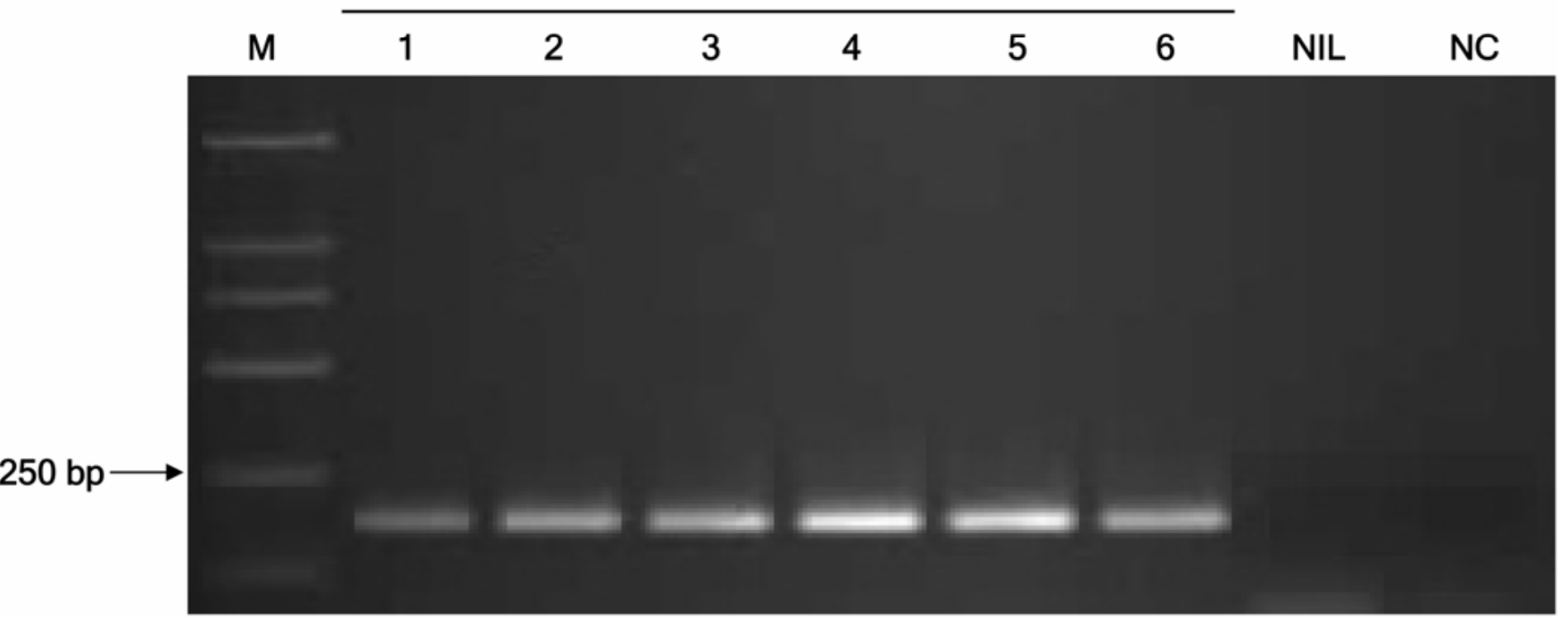

Fig. 5. Detection of Puccinia striiformis f. sp. tritici in wheat leaves of 1 to 6 days after inoculation with urediniospores of race CYR-32. Polymerase chain reaction (PCR) amplification was performed using the specific primer pair PSF/PSR. PCR products were separated by $1 \%$ agarose gel electrophoresis. NIL $=$ noninoculated leaves, $\mathrm{NC}=$ negative control (sterile water), and M = DNA ladder (DL-2000, Takara).
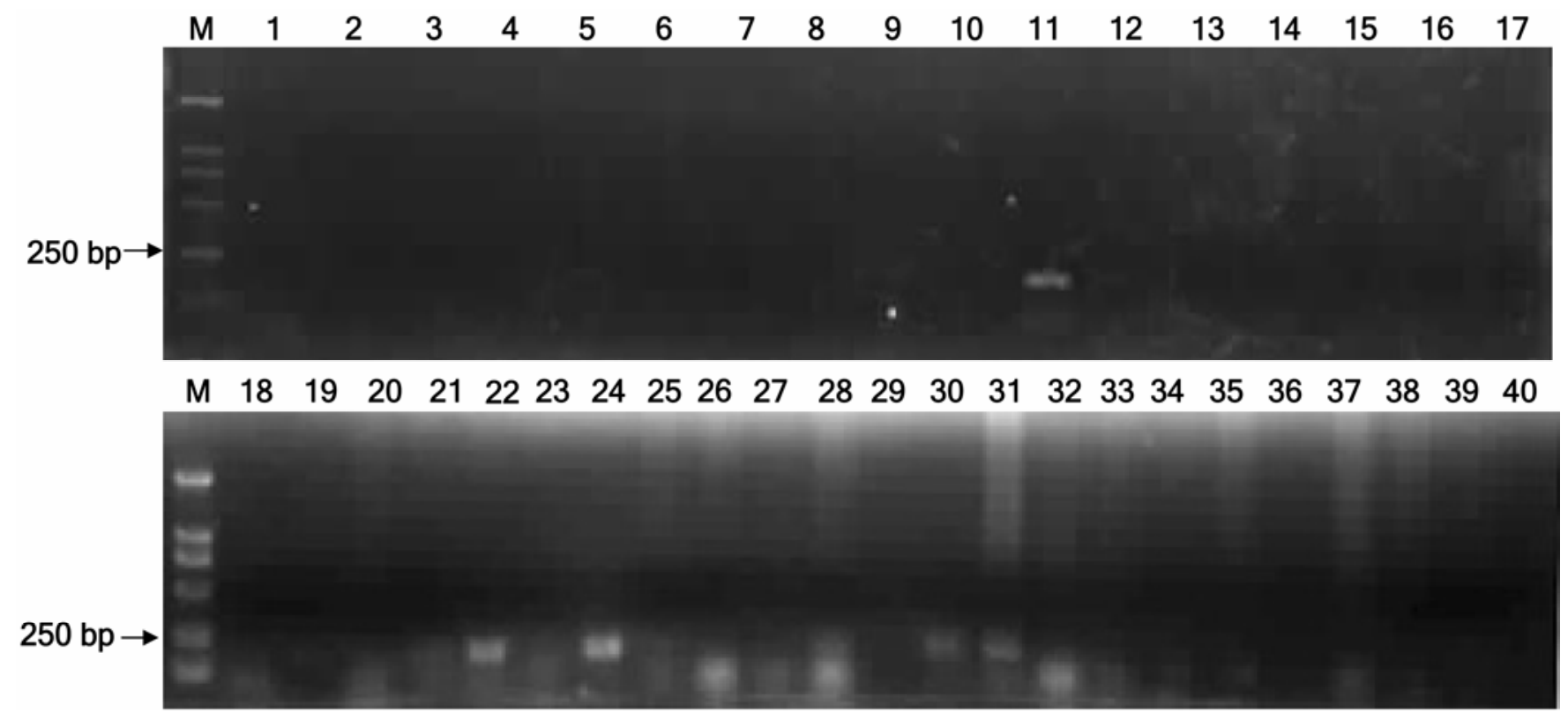

Fig. 6. Polymerase chain reaction (PCR) amplification using DNA extracted from wheat leaves sampled around stripe rust foci in wheat fields. PCR products were resolved by $1 \%$ agarose gel. $\mathrm{M}=$ DNA ladder (DL-2000, Takara).

PCSIRT of Education Ministry of China (200558), the 111 Project (B07049), and Youth Sci-Research Fund of Northwest A\&F University (04ZM087), P. R. China. We thank T. E. Coram for helpful assistance in writing the manuscript.

\section{LITERATURE CITED}

1. Cao, L. H., Kang, Z. S., Zheng, W. M., Huang, L. L., and Li, Z. Q. 2005. The development of SCAR detection marker of Puccinia striiformis f. sp. tritici race CY31 in China. Mycosystema 24:98-103

2. Chen, X. M. 2005. Epidemiology and control of stripe rust (Puccinia striiformis f. sp. tritici) on wheat. Can. J. Plant Pathol. 27:314-337.

3. Chen, X. M., Line, R. F., and Leung, H. 1993. Relationship between virulence variation and DNA polymorphism in Puccinia striiformis. Phytopathology 83:1489-1497.

4. Chen, X. M., Moore, M. K., and Wood, D. A. 2003. Epidemiology and control of stripe rusts of wheat and barley in the United States. Pages 118 in: Abstr. 8th Int. Congr. Plant Pathol. Vol. 2. Christchurch, New Zealand.

5. Chinang, Y. C., Chou, C. H., Lee, P. R., and Chiang, T. Y. 2001. Detection of leafassociated fungi based on PCR and nucleotide sequence of the ribosomal internal transcribed (ITS) in Miscanthus. Bot. Bull. Acad. Sin. 42:39-44.

6. Edel, V. 1998. Polymerase chain reaction in mycology. Pages 1-20 in: Application of Polymerase Chain Reaction in Mycology. D. K. Aroa, C. A. Reddy, P. D. Bridge, and R. P. Elander, eds. CAB Publishing, New York.

7. Freeman, J., War, D. E., Calderon, C., and McCartney, A. 2002. A polymerase chain reaction (PCR) assay for the detection of inoculum of Sclerotinia sclerotiorum. Eur. J. Plant Pathol. 108:877-886.

8. Ge, Y. Y., and Guo, J. H. 2003. Analysis of ITS sequence and PCR protocol for the detection of Clavibacter fangii, the causal agent of wheat seedling wilting disease. Acta Phytopathol. Sin. 33:198-202.

9. Ghignone, S., and Migheli, Q. 2001. Nuovi strumenti di diagnosi per funghi fitpatogeni. Inf. Fitopatol. 51:7-22.

10. Ghignone, S., Tamietti, G., and Girlanda, M 2003. Development of specific PCR primers for identification and detection of Rhizopycnis vagum. Eur. J. Plant Pathol. 109:861-870.

11. Henson, J. M., and French, R. 1993. The polymerase chain reaction and plant disease diagnosis. Annu. Rev. Phytopathol. 31:81-109.

12. Kang, Z. S., Cao, L. H., Zheng, W. M., Huang, L. L., and Li, Z. Q. 2005. Selection and foundation of a race specific molecular marker for wheat stripe rust race CY29 in China. J. Northwest Sci.-Tech. Univ. Agric. For. 33:53-56.

13. Klein, P. G., and Juneja, V. K. 1997. Sensitive detection of viable Listeria monocytogenes by reverse transcription PCR. Appl. Environ. Mi- 
crobiol. 63:4441-4448.

14. Li, Z. Q., and Shang, H. S. 1989. Pages 211221 in: Wheat Stripe Rust and Its Control in China. Shanghai Science and Technology Press.

15. Line, R. F. 2002. Stripe rust of wheat and barley in North America: a retrospective historical review. Annu. Rev. Phytopathol. 40:75118.

16. Line, R. F., and Chen, X. M. 1995. Success in breeding for and managing durable resistance to wheat stripe rusts. Plant Dis. 79:1254-1255.

17. Line, R. F., and Qayoum, A. 1991. Virulence, aggressiveness, evolution, and distribution of races of Puccinia striiformis (the causal of stripe rust of wheat) in North America, 19861987. U. S. Dep. Agric. Tech. Bull. 1788.

18. Lodhi, M. A., Ye, G. N., Weeden, N. F., and Reisch, B. I. 1994. A simple and efficient method for DNA extraction from grapevine cultures and vitis species. Plant Mol. Biol. Rep. 12:6-13.

19. Mutasa, E. S., Chwarszczynska, D. M., Adams, M. J., Ward, E., and Asher, M. J. C. 1995. Development of PCR for the detection of Polymyxa betae in sugar beet roots and its application in field studies. Physiol. Mol. Plant Pathol. 47:303-313.

20. Röbbelen, G., and Sharp, E. L. 1978. Mode of inheritance, interaction and application of genes conditioning resistance to yellow rust. Fortschr. Pflanzenzücht. 9:1-88.

21. Saari, E. E., and Prescott, J. M. 1985. World distribution in relation to economic losses. Pages 260-298 in: The Cereal Rusts, Vol. 2. A. P. Roelfs and W. R. Bushnell,, eds. Academic Press, Orland0, FL.

22. Sambrook, J., and Russell, D. 2001. Molecular Cloning: A Laboratory Manual. Cold Spring Harbor Laboratory Press, Cold Spring Harbor, NY.

23. Schena, L., Nigro, F., Ippolito, A., and Gal- litelli, D. 2004. Real-time quantitative PCR: a new technology to detect and study phytopathogenic and antagonistic fungi. Eur. J. Plant Pathol. 110:893-908.

24. Shan, W. X., Chen, S. Y., Zhang, G. Y., Wu, L. R., and Li, Z. Q. 1997. Identification of a family of dispersed moderately repetitive DNA sequences in an obligate fungal plant pathogen Puccinia striiformis. Sci. China (Ser. B) 27:241-246.

25. Sholberg, P. L., O'Gorman, D. T., and Bedford, K. E. 2004. Use of PCR and DNA hybridization for identification of pear powdery mildew caused by Podosphaera leucotricha. Can. J. Plant Pathol. 26:199-204.

26. Stubbs, R. W. 1985. Stripe rust. Pages 61-101 in: The Cereal Rusts, Vol. 2. A. P. Roelfs and W. R. Bushnell, eds. Academic Press, Orlando, FL.

27. Taylor, G., Wang, X., and Jabaji-Hare, S. H. 2003. Detection of the mycoparasite Stachybotrys elegans, using primers with sequencecharacterized amplification regions in conventional and real-time PCR. Can. J. Plant Pathol. 25:49-61.

28. Wan, A. M. 2000. The status of occurrence and research on wheat stripe rust in China. World Agric. 5:39-40.

29. Wan, A. M., Wu, L. R., Jin, S. L., Jia, Q. Z., Yao, G., Yang, J. X., Wang, B. T., Li, G. B., and Yuan, Z. Y. 2002. Occurrence of wheat stripe rust and monitoring of physiological races of Puccinia striiformis f. sp. tritici in China in 2000-2001. Plant Prot. 28:5-9.

30. Wan, A. M., Zhao, Z., Chen, X. M., He, Z. H., Jin, S. L., Jia, Q. Z., Yao, G., Yang, J. X., Wang, B. T., Li, G. B., Bi, Y. Q., and Yuan, X. Y. 2004. Wheat stripe rust epidemic and virulence of Puccinia striiformis f. sp. tritici in China in 2002. Plant Dis. 88:896-904.

31. Ward, E. 1994. Use of the polymerase chain reaction for identifying plant pathogens. Pages
143-160 in: Ecology of Plant Pathogens. J. P. Blakeman and B. C. Williamson, eds. Oxford University Press, Wallingford, UK.

32. Ward, E., and Adams, M. J. 1998. Analysis of ribosomal DNA sequence of Polymyxa species and related fungi and the development of genus- and species-specific PCR primers. Mycol. Res. 102:965-974.

33. Ward, E., and Bateman, G. L. 1999. Comparison of Gaeumanomyces- and Phialophora-like fungal pathogens from maize and other plants using DNA methods. New Phytol. 141:323331.

34. White, T. J., Bruns, T., and Lee, S. 1990. Amplification and direct sequencing of fungal ribosomal RNA genes for phylogentics. Pages 315-322 in: PCR Protocols: A Guide to Methods and Applications. M. A. Inns, D. H., Gelfand, J. J. Sninsky, and T. J. White, eds. Academic Press, San Diego, CA.

35. Yang, P. W., Li, J. R., Yang, Q. Z., Zeng, L., and Wang, Q. 2003. Cloning and sequencing the internal transcribed spacer of the ribosoma gene of Plasmodiophora brassicae and applying it in detecting the pathogen. J. Yunnan Agric. Univ. 18:228-233

36. Zamnino, P., Roelfs, A., and Szabo, L. 1992. Phylogenetic relatedness among species and formae specials of cereal rust fungi by DNA sequence analysis of the rDNA internal transcribed spacer (ITS) region. Proc. Eur Mediterr. Cereal Rusts Powdery Mildew Conf. 8:60-62.

37. Zhang, J. X., Fernando, X. G. D., and Remphery, W. R. 2005. Molecular detection of Apiosporina morbosa, causal agent of black knot in Prunus virginiana. Plant Dis. 89:815821.

38. Zhang, Z. G., Wang, Y. C., and Zheng, X. B. 2004. Sequence analysis of ITS of the ribosomal RNA gene repeat of Phytophthora sojae and P. medicaginis. Mycosystema 22:524-548. 